International Journal of Civil, Structural, Environmental and Infrastructure Engineering Research and Development (IJCSEIERD) ISSN (P): 2249-6866; ISSN (E): 2249-7978

Vol. 11, Issue 2, Apr 2021, 31-42

(C) TJPRC Pvt. Ltd.

\title{
STUDY AND ANALYSIS OF THE COMPRESSIVE STRENGTH OF CONCRETE USING DIFFERENT TYPES OF CEMENT IN GHANA
}

\section{EILEEN GOODY GANS-LARTEY \& MA QINYONG}

School of Civil Engineering and Architecture, Anhui University of Science and Technology,

Huainan 232001, Anhui, China

\begin{abstract}
Concrete consist of coarse aggregates, sand (fine aggregate), cement and water which are mixed together to provide a uniform mixture. Admixtures are sometimes added to the mix for some special works. The cement used is basically Portland cement which acts as the binder to the aggregates used in the concrete mix. The cement reacts with the water in the mix chemically to cause the paste to harden. Some of the cement that are being sold may not be up to standard and this may be traced to negligence on the part of the manufacturers by paying very little attention to the quality and also the regulatory body does not put strict measures to enforce the required standard. This may cause the failure of the cement to perform its intended use in the concrete thereby causing failure of structure. There has been competition between the types of cement to be used in the construction field within the country. The aim of this study was to analyze the strength of concrete using different types of cement for the mix. The analysis was based on the compressive strength of concrete using a mix ratio for C30 grade. The strength was checked for 3days, 7days, 14days and 28days respectively and cement grade used for all test was the grade 32.5R. The materials (especially) the sand was good enough to give the right results. The same quantity of aggregates (fine and coarse), cement and water were used throughout for all the types of cement used in the mix. No additive or admixture was used in any of the mix. The tests carried out include the grading test, slump test at its fresh state while compressive strength was carried out for the hardened concrete.

The compressive strength at the 3 days showed Diamond cement produced $15.59\left(\mathrm{~N} / \mathrm{mm}^{2}\right)$, Ghacem cement produced $28.06\left(\mathrm{~N} / \mathrm{mm}^{2}\right)$ and Cimaf cement $18.85\left(\mathrm{~N} / \mathrm{mm}^{2}\right)$. At the 28 days showed that Diamond cement produced $31.75\left(\mathrm{~N} / \mathrm{mm}^{2}\right)$, Ghacem cement produced $42.79\left(\mathrm{~N} / \mathrm{mm}^{2}\right)$ and Cimaf cement $26.43\left(\mathrm{~N} / \mathrm{mm}^{2}\right)$. The study concluded that Ghacem cement has the highest strength at 3 days and 28 days with a compressive strength of $28.06\left(\mathrm{~N} / \mathrm{mm}^{2}\right)$ and $42.79\left(\mathrm{~N} / \mathrm{mm}^{2}\right)$ respectively. It was recommended that Ghacem cement should be chosen for high rise concrete buildings in Ghana.

KEYWORDS: Compressive Strength, Concrete, Cement, Grading test, Slump Test
\end{abstract}

Received: Feb 16, 2021; Accepted: Mar 04, 2021; Published: Mar 15, 2021; Paper Id.: IJCSEIERDAPR20214

\section{INTRODUCTION}

Concrete is a composite building material which is made up of aggregates, water and cement. It was used extensively in areas such as Egypt, Greece and the Middle East, for building before the Romans extensively used it for road construction. In the use of it the components of concrete varied and from the mid-eighteen centuries till now concrete has been the most common building material. Concrete is said to be good when it has to satisfy performance requirements in the plastic and harden states. In the plastic state the concrete should be workable and free from segregation and bleeding and in the harden state concrete should be strong, durable and impermeable. The evolution of concrete has pass through plain concrete, reinforced concrete, precast concrete, pre-stressed concrete to the contemporary concrete. Plain concrete made of Portland cement, coarse and fine aggregate and water is usually 
called the first generation of concrete while the steel bar-reinforced concrete is the second generation concrete (Ede et, al., 2015). Concrete has been in existence since the Roman Empire and one of the important ingredients in the mixture of concrete is cement. In 1824, an English man name Joseph Aspdin invented Portland cement by burning finely ground chalk and clay in a kiln until the carbon dioxide was removed and it was named "Portland" cement because it resembled the high-quality building stones found in Portland England. The reaction of cement with water causes the cement in the concrete to act as a binding agent. Portland cement is not a simple chemical compound; it is a mixture of many compounds. Four of these make up $90 \%$ or more of the weight of Portland cement, tricalcium silicate, dicalcium silicate, tricalcium aluminate and tetracalcium alumnoferrite (Kosmatka et al., 2002). The initial reaction must be slow enough to allow time for the concrete to be transported and placed. Once the concrete has been placed and finished, rapid hardening is desirable. Gypsum added at the cement mill when clinker is ground, acts as a regular of the initial rate of setting of Portland cement. Other factors that influence the rate of hydration include cement fineness, admixture, amount of water added and temperature of the material at the time of mixing (Ede et, al., 2015). This study is based on three brands of cement namely Diamond cement, Ghacem cement and Cimaf cement. All the cements used have the grade of $32.5 \mathrm{R}$.

Concrete material can have positive or negative impact on a society. This comes about due to the constituent of the concrete. One of the constituents of concrete which can cause a collapse of a structure is the cement used in the concrete mix. Cement reacts with water in concrete mix to bind the constituents together and cause it to harden. Cement of the required quality and standard enhances the quality and durability of building structures.

There is a competition of the patronization of cement in the country. The big question is that, is the competition based on the cost or the strength of the cements. Most of the consumers do not check or care about the strength of the cement in the concrete but the cost of the cement. The strength of every cement is boldly written on its cover but does all the different brands of cement having the same grade written on them actually have the same strength? If even they have the same strength, is the strength the same for the different types (brands) of cement used in the mix throughout the period of the curing process till the maximum 28days curing age? This research seeks to find the compressive strength of concrete with different types (brand) of cements for curing period of 3days,7days, 14days and 28days.

\section{EXPERIMENT}

\section{RAW and TEST MATERIALS}

The tests conducted focused on three main areas namely the grading test of aggregate, slump test and compressive strength test of the cube. Materials used also include Portland cement of different brands., Portable drinking water, Fine aggregates (river sand): taken from an ongoing project in the Greater Accra Region Tema Port Expansion Project and Coarse aggregates (Crushed rock): ranging from 10 to $20 \mathrm{~mm}$ grading size for the aggregate, also from the same source as the fine aggregate (river sand) and the apparatus used include head pan, wheelbarrow, shovel, trowel 150mm cube box,, Slump cone, tamping rod, weighing machine and electronic compressive cube crushing machine

\section{Test Method}

\section{SIEVE ANALYSIS}

\section{Grading of Aggregates}

Sieve analysis was used to determine the grading of aggregates in accordance with (BS EN 933-1 and 3; BS EN 1097-5).

\section{Fine Aggregates}


The sieve sizes used for the grading of the fine aggregates includes the following; $5 \mathrm{~mm}, 4 \mathrm{~mm}, 3.15 \mathrm{~mm}, 2 \mathrm{~mm}, 1 \mathrm{~mm}$, $0.5 \mathrm{~mm}, 0.25 \mathrm{~mm}, 0.125 \mathrm{~mm}, 0.063 \mathrm{~mm}$, Pan.

\section{Procedure}

The sieve sizes were stacked in arrangement from biggest size to the smaller size and an empty pan under it all. The weighing machine was set to zero and an empty pan was weighed and recorded. The fine aggregates for the test was put into the empty pan and measured for 502g on the weighing machine. The weighed aggregates were put into the sieve number $5 \mathrm{~mm}$ and shake for about 15 minutes. After 15 minutes of shaking, the particles retained on the sieve number $5 \mathrm{~mm}$ was separated and weighed. The value was recorded in a table and the particles retained in each of the sieves were weighed by pouring it into the empty pan weighed earlier and noted in the table. The percentages of the weight retained in each sieve was calculated and noted in the table. The percentage of the weight which passed each sieve was also calculated and noted.

\section{Coarse aggregates}

The coarse aggregate grading test was performed for two different range of aggregate size, that is $10 / 14$ and 14/20. The same grading test was performed for the different range of aggregates with different sieve sizes. The sieve sizes for aggregate size $10 / 14$ were $16 \mathrm{~mm}, 14 \mathrm{~mm}, 12.5 \mathrm{~mm}, 10 \mathrm{~mm}, 8 \mathrm{~mm}, 6.3 \mathrm{~mm}, 5 \mathrm{~mm}, 4 \mathrm{~mm}, 3.15 \mathrm{~mm}, 2 \mathrm{~mm}, 1 \mathrm{~mm}$. and sieve sizes for aggregate $14 / 20$ were $20 \mathrm{~mm}, 16 \mathrm{~mm}, 14 \mathrm{~mm}, 12.5 \mathrm{~mm}, 10 \mathrm{~mm}$ and $8 \mathrm{~mm}$. The same grading process used for the fine aggregates was used for the aggregate size $14 / 20$ and 10/14 with different sieve sizes.

\section{BATCHING}

The method adopted was the weighing method of batching. All the constituent used for the mixing or production of the concrete were weighed on a digital weighing machine to achieve a concrete mix ratio of 1: 1.5: 3 . Before the start of the batching, the container used for the batching was put on the weighing machine and then set to zero. The fine aggregates were weighed to achieve $40.6 \mathrm{~kg}$, the coarse aggregates were weighed for $77.4 \mathrm{~kg}$, the cement used was weighed for $28.0 \mathrm{~kg}$ and the water used was also weighed for $12.2 \mathrm{~kg}$ which amount to a water cement ratio of 0.44 . The weight specified above was used for all the 3 different type of cement used.

\section{CONCRETE PRODUCTION}

Manual means or hand mixing method was adopted, shovel was used to mix the various sample and the mix was done on a clean surface. All the 3 different type of mix was done on 3 different surfaces to prevent any leftover cement from one mix to be added to any other concrete mix. The concrete after mix was checked for workability.

\section{CUBES MOULDING}

The concrete was poured into the 150x150x150mm cube box. The cube box was primed with molding oil in accordance to standards to prevent the concrete adhering to the surface of the cube boxes and also to allow for easy de-shuttering of the box (moulds). Twelve concrete cubes were moulded for each of the brand of cement used.

\section{COMPACTION}

The tamping rod was used to compact the concrete in the cube box. The concrete was poured two times into each of the cube boxes. All sample specimens were compacted with the rod 25 times for each pour before trowel used for finishing the 
surface.

\section{SLUMP TEST}

The slump test was conducted for all the 3 mixes. Part of the concrete mixed was used for the slump test. The concrete was poured into the cone 3 times and each pour was rodded (compacted) for 25 times. After the rodding, the top surface was dressed and the cone was slowly removed from the concrete in its plastic state. The cone was placed closer to the concrete and the slump was measured and recorded.

\section{CURING}

The curing method that was adopted for the study was the wholly water submerged as it is one of the best methods of curing concrete. All the concrete cubes were de-shuttered the next day after cast and immediately submerged into a pan of water. The curing was done for 3days, 7days, 14days and 28days. After each of the days stated above, 3 number of the concrete cubes for each of the different types (brands) of cement in mix was sent for compressive strength test.

\section{COMPRESSIVE STRENGTH TEST}

In most cases the type of construction initially chosen will have sufficient design and material strength data available to satisfy that the method and type of construction chosen is suitable for the structure to be built. Material testing and practice plays a vital part of the material and the satisfaction of all parties concerned in the production of concrete. To achieve this, the strength of the concrete was tested.

\section{Testing of Cube Samples}

Compressive strength gained was determined for all sample specimens by using a compressive testing machine. The test specimen of $150 \mathrm{~mm}$ cube was first removed from the submerged water in the curing pan and wiped clean. The cubes were then place on a weighing machine to weigh the spacemen and the weights recorded before taking to the compression test machine for crushing. The sample specimens were centered on the compression machine and the loads was applied to the cube specimen. The load used to compress the specimens and the compressive strengths were recorded. The average compressive strength for each of the curing age for the three different brands of cement used in the concrete was recorded. The sample specimen was crushed for 3days, 7days, 14days and 28 days respectively. All the results were tabulated for each of the concrete with the different type (brand) of the cement used and compared to draw conclusion.

\section{TEST RESULTS AND ANALYSIS \\ GRADING TEST OF AGGREGATES}

The result of the grading test performed on the samples is summarized with details of the tests and the graphs of the results are presented below;

\section{Grading and Sieve Analysis for Sand}

The grading test performed on the river sand is given in table 4.1 below. The table indicates that $97.00 \%$ of the sample passed through the $3.15 \mathrm{~mm}$ sieve. This could be classified as sand due to the fact that the percentage that passed through the sieve was more than 50\%. The particle size distribution curve of the sand showed in figure 4.1 below indicates that the aggregates used for this study has all the category (constituent) of a sand which ranges from $0.06 \mathrm{~mm}-2.0 \mathrm{~mm}$ and also has about $3.0 \%$ of fine gravels within it as compared to the standard soil type based on particle size. This also shows that the 
aggregates are well graded and therefore suitable for making good concrete. The BS gives an envelope within which the fine aggregate must lie.

Table 1: Sieve Analysis of Sand

\begin{tabular}{|c|c|c|c|c|}
\hline Sieve Size (mm) & Weight Retained & \% Retained & Cumulative \% Retained & \% Passing \\
\hline 5 & 8 & 1.59 & 1.59 & 98.41 \\
\hline 4 & 4 & 0.80 & 2.39 & 97.61 \\
\hline 3.15 & 3 & 0.60 & 2.99 & 97.00 \\
\hline 2 & 20 & 3.98 & 6.97 & 93.03 \\
\hline 1 & 40 & 7.97 & 14.94 & 85.06 \\
\hline 0.5 & 75 & 14.94 & 29.88 & 70.00 \\
\hline 0.25 & 144 & 28.69 & 58.57 & 41.43 \\
\hline 0.125 & 166 & 33.06 & 91.63 & 8.37 \\
\hline 0.063 & 40 & 7.97 & 99.60 & 0.40 \\
\hline Pan & 2 & 0.40 & 100.00 & 0 \\
\hline
\end{tabular}

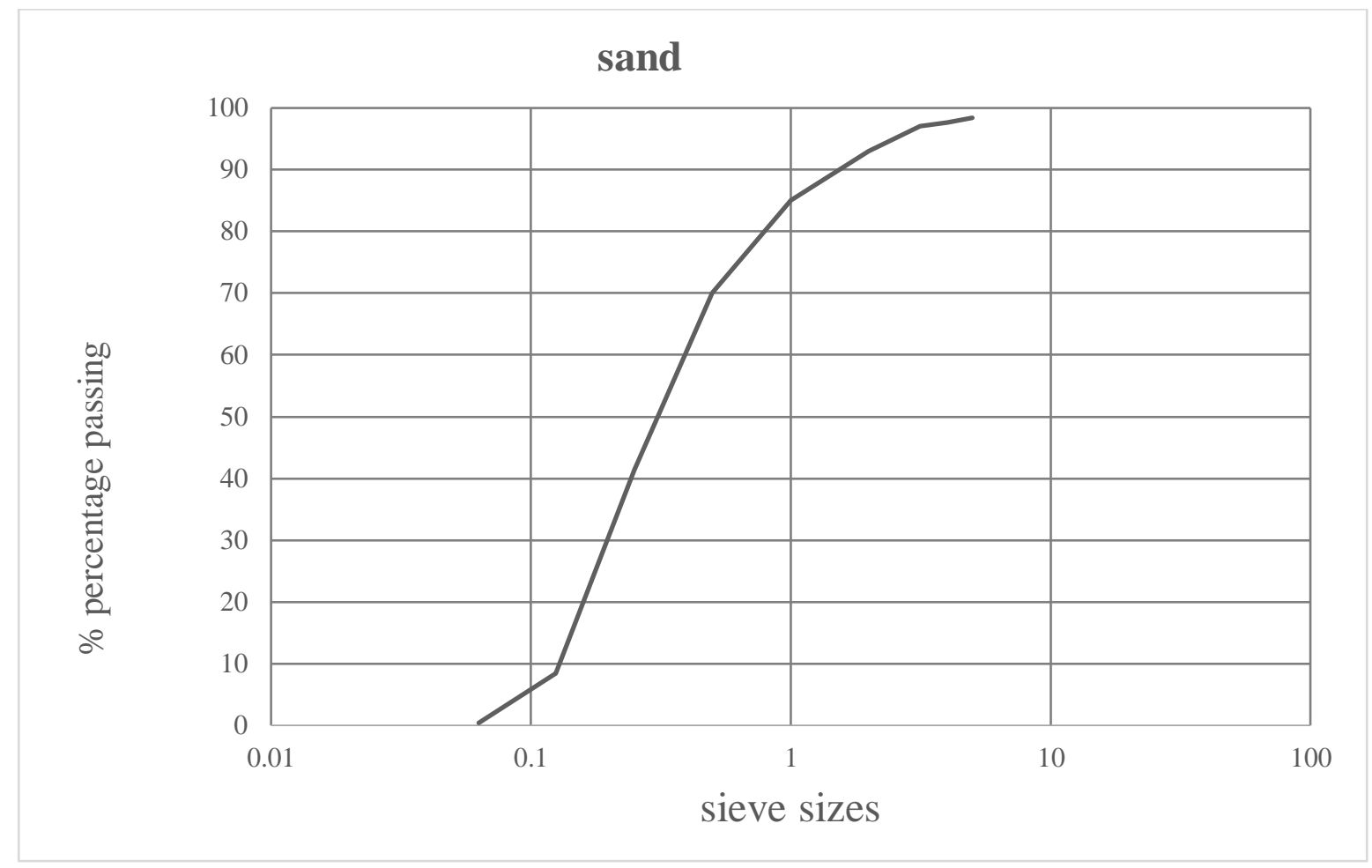

Figure 1: Grading and Sieve Analysis for Sand

\section{Grading and Sieve Analysis for Coarse Aggregates (10/14)}

The grading test performed on the (10/14) aggregates showed in the Table 4.2 below indicates that $96.73 \%$ of the sample passed through the $16 \mathrm{~mm}$ sieve. This shows that most of the aggregate sizes in this test are less than $16 \mathrm{~mm}$ due to the fact that the percentage that passed through the sieve $16 \mathrm{~mm}$ was more than $50 \%$. The particle size distribution curve of the coarse aggregates showed in figure 4.2 below indicates that this particular aggregate is uniformly graded because it lacks some of the category (constituents) of the aggregates as compared to the standard soil type based on particle size. 
Table 2: Grading for Coarse Aggregate

\begin{tabular}{|c|c|c|c|c|}
\hline Sieve Size (mm) & Weight Retained & \% Retained & Cumulative \% Retained & \% Passing \\
\hline 16 & 64 & 3.274 & 3.274 & 96.73 \\
\hline 14 & 49 & 2.506 & 5.78 & 94.22 \\
\hline 12.5 & 249 & 12.737 & 18.517 & 81.48 \\
\hline 10 & 826 & 42.251 & 60.768 & 39.23 \\
\hline 8 & 615 & 31.458 & 92.226 & 7.77 \\
\hline 6.3 & 99 & 5.064 & 97.29 & 2.71 \\
\hline 5 & 12 & 0.614 & 97.931 & 2.07 \\
\hline 4 & 8 & 0.409 & 98.34 & 1.66 \\
\hline 3.15 & 13 & 0.665 & 99.005 & 1.00 \\
\hline 2 & 10 & 0.511 & 99.515 & 0.49 \\
\hline Pan & 10 & 0.511 & 100.00 & 0 \\
\hline
\end{tabular}

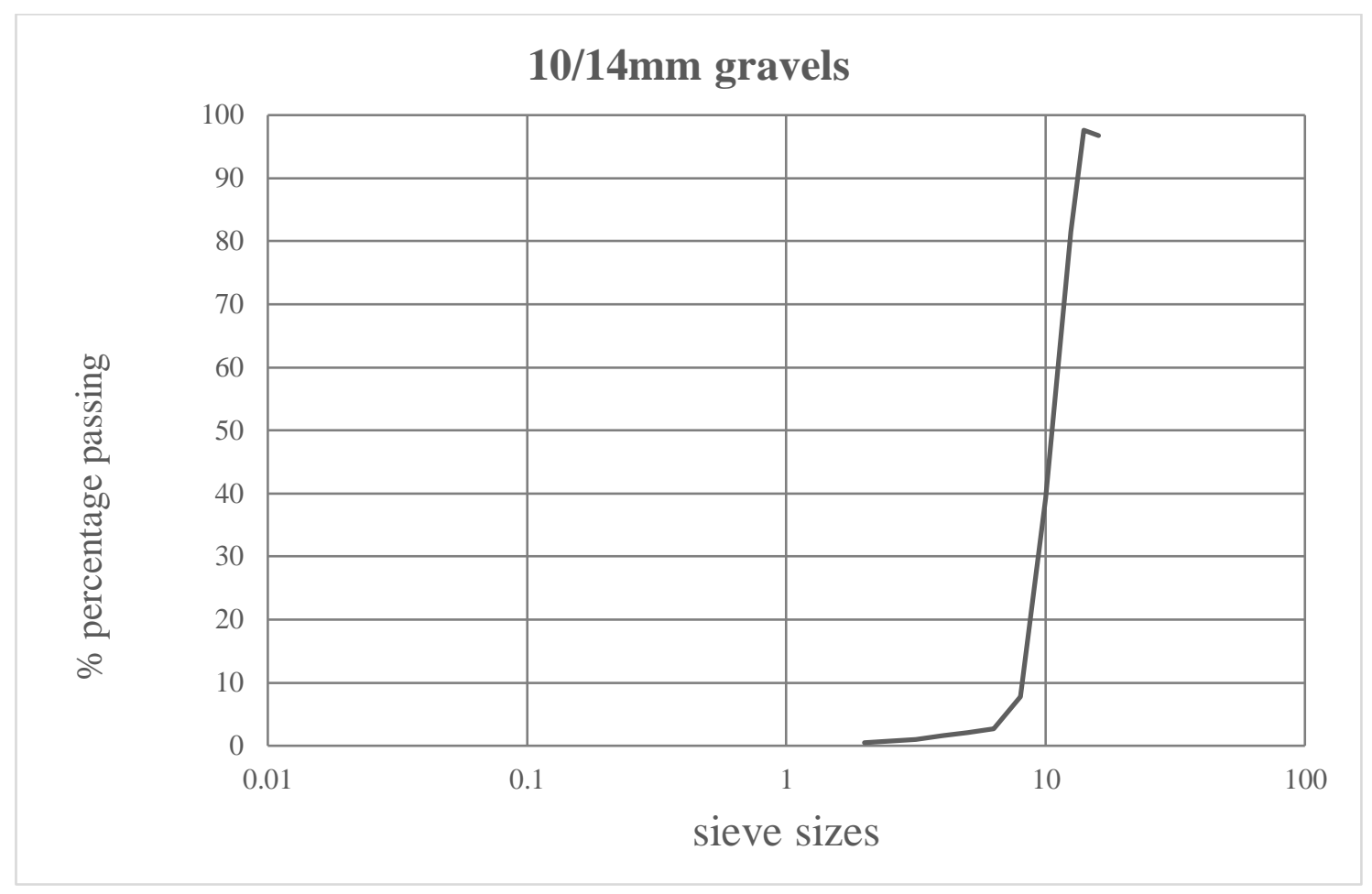

Figure 2: Grading and Sieve Analysis for Coarse Aggregates

\section{Grading and Sieve Analysis for Coarse Aggregates (14/20)}

The grading test performed on the (14/20) aggregates showed in the Table 4.3 below indicates that $56.50 \%$ of the sample passed through the $20 \mathrm{~mm}$ sieve. This shows that most of the aggregate sizes in this test is less than $20 \mathrm{~mm}$ due to the fact that the percentage that passed through the sieve $20 \mathrm{~mm}$ was more than $50 \%$ and also greater than $14 \mathrm{~mm}$ size. The particle size distribution curve of the coarse aggregates showed in figure 4.3 below indicates that this particular aggregate is also uniformly graded. The coarse aggregates (10/14) and the coarse aggregates (14/20) were added or mixed together to make it well graded and also suitable for making good concrete. 
Table 3: Grading for Coarse Aggregate (14/20)

\begin{tabular}{|c|c|c|c|c|}
\hline Sieve Size (mm) & Weight Retained & \% Retained & Cumulative \% Retained & \% Passing \\
\hline 20 & 1490 & 43.50 & 43.50 & 56.50 \\
\hline 16 & 1460 & 42.63 & 86.13 & 13.87 \\
\hline 14 & 326 & 9.52 & 95.65 & 4.35 \\
\hline 12.5 & 122 & 3.56 & 99.21 & 0.79 \\
\hline 10 & 17 & 0.50 & 99.71 & 0.29 \\
\hline Pan & 10 & 0.29 & 100.00 & 0 \\
\hline
\end{tabular}

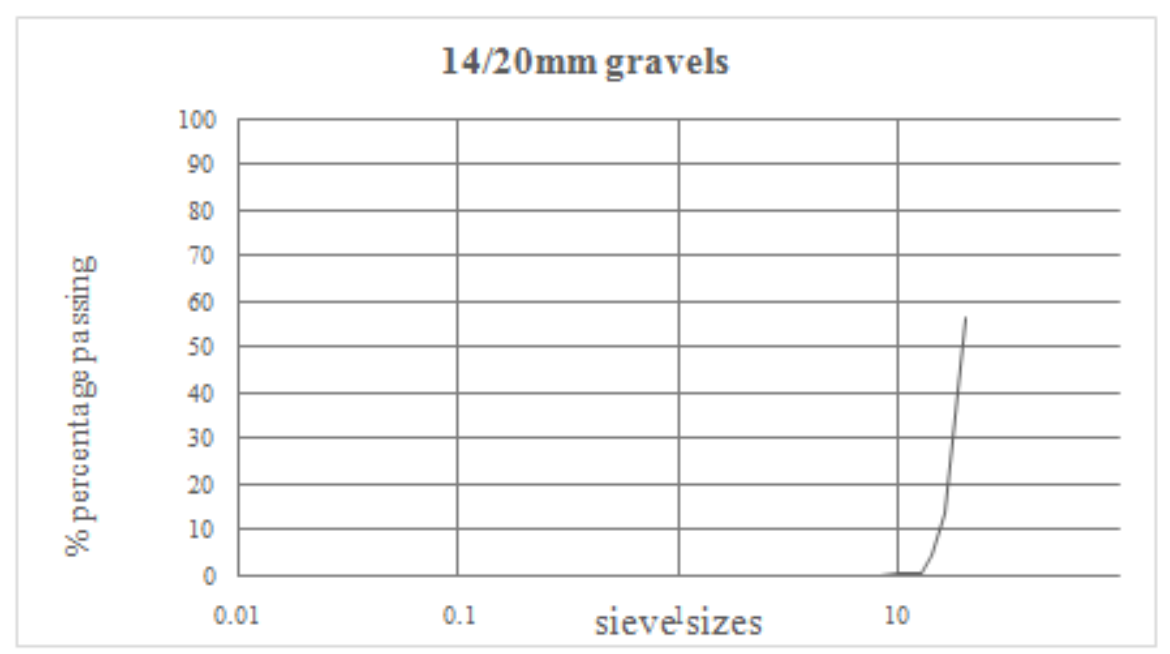

Figure 3: Grading and Sieve Analysis for Coarse Aggregates

\section{SLUMP TEST ANALYSIS}

Table 4: Slump Test Results of the Concrete mix with the Various Types (Brand) of Cement

\begin{tabular}{|l|c|c|c|}
\hline Cement Brand & $\begin{array}{c}\text { Height of Slump Cone } \\
(\mathbf{m m})\end{array}$ & Height of Collapse (mm) & Slump (mm) \\
\hline Diamond & 300.00 & 225.00 & 75.00 \\
\hline Ghacem & 300.00 & 204.00 & 96.00 \\
\hline Cimaf & 300.00 & 214.00 & 86.00 \\
\hline
\end{tabular}

From the table above, it can be deduced that the Ghacem cement has the highest slump value followed by Cimaf cement and then Diamond cement. This shows that the Ghacem cement in the concrete was more workable compared to the other two cements with all the three cements having the same mix proportions for all the mix. The next to Ghacem cement was Cimaf cement and then Diamond cement. All this indicates that the reaction of water with Ghacem cement for concrete setting is slow compared to Cimaf and Diamond cement. Therefore, Diamond cement in concrete will set faster followed by Cimaf and then Ghacem respectively.

\section{COMPRESSIVE STRENGTH TEST}

The complete compressive strength test results for concrete samples with different types (brands) of cement are presented in Table 4.5 showing the cube crushing at $3,7,14$, and 28 days respectively for each of the cement brands. 
Table 5: Compressive Strength Test Result

\begin{tabular}{|c|c|c|c|c|c|}
\hline $\begin{array}{c}\text { Cement } \\
\text { Brand }\end{array}$ & Days & Test 1 & Test 2 & Test 3 & Average Test $\left(\mathbf{N} / \mathbf{M}^{\mathbf{2}}\right)$ \\
\hline \multirow{4}{*}{ Diamond } & 3 & 15.65 & 15.52 & 15.61 & 15.59 \\
\cline { 2 - 6 } & 7 & 24.21 & 24.29 & 24.23 & 24.24 \\
\cline { 2 - 6 } & 14 & 27.32 & 27.40 & 27.35 & 27.36 \\
\cline { 2 - 6 } & 28 & 31.63 & 31.85 & 31.76 & 31.35 \\
\hline \multirow{4}{*}{ Ghacem } & 3 & 27.98 & 28.10 & 28.09 & 28.06 \\
\cline { 2 - 6 } & 7 & 36.92 & 37.12 & 37.01 & 37.02 \\
\cline { 2 - 6 } & 14 & 39.13 & 39.31 & 39.26 & 42.23 \\
\hline \multirow{3}{*}{ Cimaf } & 28 & 42.70 & 42.78 & 42.89 & 18.85 \\
\cline { 2 - 6 } & 3 & 18.73 & 18.87 & 18.95 & 24.33 \\
\cline { 2 - 6 } & 7 & 24.20 & 24.39 & 24.41 & 25.24 \\
\hline
\end{tabular}

Table 2.6 shows the compressive strength results for Diamond cement at different curing days of 3, 7, 14 and 28 days respectively.

Table 6: Compressive Strength Test of Concrete Mixed with Diamond Cement

\begin{tabular}{|c|c|c|c|c|c|}
\hline $\begin{array}{c}\text { Curing Age } \\
\text { (Days) }\end{array}$ & Date Cast & Date Tested & $\begin{array}{c}\text { Weight of } \\
\text { Cubes (kg) }\end{array}$ & $\begin{array}{c}\text { Load Applied } \\
\text { (KN) }\end{array}$ & $\begin{array}{c}\text { Average } \\
\text { Compressive } \\
\text { Strength } \\
\left(\mathbf{N} / \mathbf{m m}^{2}\right)\end{array}$ \\
\hline 3 & $13 / 05 / 2018$ & $16 / 05 / 2018$ & 8.428 & 350.82 & 15.59 \\
\hline 7 & $13 / 05 / 2018$ & $20 / 05 / 2018$ & 8.428 & 545.38 & 24.24 \\
\hline 14 & $13 / 05 / 2018$ & $27 / 05 / 2018$ & 8.700 & 615.49 & 27.36 \\
\hline 28 & $13 / 05 / 2018$ & $10 / 06 / 2018$ & 8.428 & 714.46 & 31.75 \\
\hline
\end{tabular}

From the Table.6 above Diamond cement, obtain the lowest compressive strength for the least curing age which was at day 3 with a strength of $15.59 \mathrm{~N} / \mathrm{mm}^{2}$. This was the lowest strength among all the three brands of cement used in the mix but in 7 days, the strength increased strongly to $24.24 \mathrm{~N} / \mathrm{mm}^{2}$ which was close to the Cimaf cement with $24.33 \mathrm{~N} / \mathrm{mm}^{2}$ after 7days. The compressive strength increased progressively as the number of days of the curing was increased to the highest age at 28 days with an average strength of $31.75 \mathrm{~N} / \mathrm{mm}^{2}$. This particular cement brand in the mix attained the second highest compressive strength after the Ghacem cement brand.

Table 7: Compressive Strength Test of Concrete Mixed with Ghacem Cement

\begin{tabular}{|c|c|c|c|c|c|}
\hline $\begin{array}{c}\text { Curing Age } \\
\text { (Days) }\end{array}$ & Date Cast & Date Tested & $\begin{array}{c}\text { Weight of } \\
\text { Cubes (kg) }\end{array}$ & $\begin{array}{c}\text { Load Applied } \\
\text { (KN) }\end{array}$ & $\begin{array}{c}\text { Average } \\
\text { Compressive } \\
\text { strength } \\
\left(\mathbf{N} / \mathbf{m m}^{\mathbf{2}}\right)\end{array}$ \\
\hline 3 & $13 / 05 / 2018$ & $16 / 05 / 2018$ & 8.524 & 631.39 & 28.06 \\
\hline 7 & $13 / 05 / 2018$ & $20 / 05 / 2018$ & 8.326 & 832.92 & 37.02 \\
\hline 14 & $13 / 05 / 2018$ & $27 / 05 / 2018$ & 8.329 & 845.35 & 39.23 \\
\hline 28 & $13 / 05 / 2018$ & $10 / 06 / 2018$ & 8.429 & 962.75 & 42.79 \\
\hline
\end{tabular}

From the Table 7 of values for Ghacem cement, it was observed that a very high compressive strength was attained at the least curing age which was at day 3 with a strength of $28.06 \mathrm{~N} / \mathrm{mm}^{2}$. In 7days, the strength of Ghacem cement in the mix keep increasing strongly to $37.02 \mathrm{~N} / \mathrm{mm}^{2}$ which was way above the two other cement used. The strength 
of the Ghacem cement in mix was the highest throughout 3, 7, 14 curing days and also attained the maximum compressive strength of $42.79 \mathrm{~N} / \mathrm{mm}^{2}$ at 28 days compared to the other two cements.

Table 8: Compressive Strength Test of Concrete Mixed with Cimaf Cement

\begin{tabular}{|c|c|c|c|c|c|}
\hline $\begin{array}{c}\text { Curing Age } \\
\text { (Days) }\end{array}$ & Date Cast & Date Tested & $\begin{array}{c}\text { Weight of } \\
\text { Cubes (kg) }\end{array}$ & $\begin{array}{c}\text { Load Applied } \\
(\mathbf{K N})\end{array}$ & $\begin{array}{c}\text { Average } \\
\text { Compressive } \\
\text { strength } \\
\left(\mathbf{N} / \mathbf{m m}^{2}\right)\end{array}$ \\
\hline 3 & $13 / 05 / 2018$ & $16 / 05 / 2018$ & 8.192 & 424.02 & 18.85 \\
\hline 7 & $13 / 05 / 2018$ & $20 / 05 / 2018$ & 8.684 & 547.40 & 24.33 \\
\hline 14 & $13 / 05 / 2018$ & $27 / 05 / 2018$ & 8.624 & 578.50 & 25.24 \\
\hline 28 & $13 / 05 / 2018$ & $10 / 06 / 2018$ & 8.429 & 586.91 & 26.43 \\
\hline
\end{tabular}

The Table 8 above shows that Cimaf cement obtain the second highest compressive strength for the least curing age of 3 days with a strength of $18.8 \mathrm{~N} / \mathrm{mm}^{2}$. In 7 days, Cimaf cement used in the mix also increased to $24.33 \mathrm{~N} / \mathrm{mm}^{2} \mathrm{which}$ is still the second highest after Ghacem cement and before Diamond cement. After the 14 days curing, this brand of cement became the lowest with a strength of $25.24 \mathrm{~N} / \mathrm{mm}^{2}$ compared to the other two brands of cement. This particular brand of cement attained the lowest compressive strength of $26.43 \mathrm{~N} / \mathrm{mm}^{2}$ after 28 days compared to the other brands used in the mix.

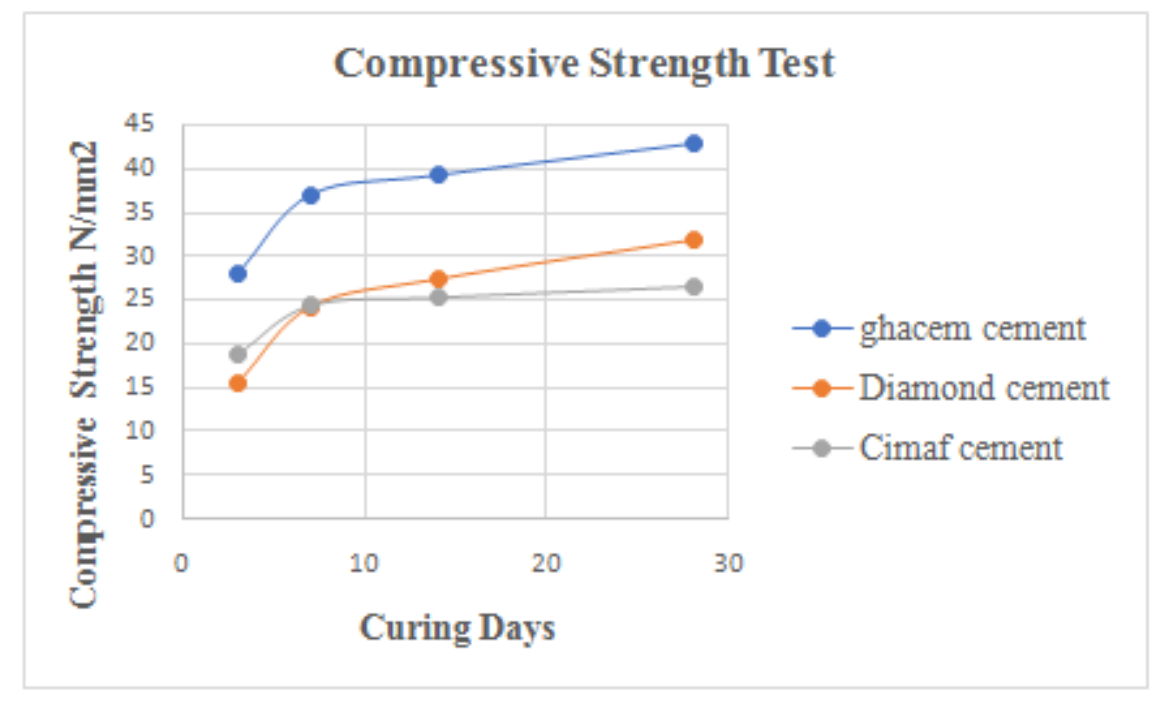

Figure 4: Compressive Strength Test Result

In summary, the results of the compressive strength of the various cement brand are represented on the figure 4 above. From the graph above, it clearly shows that the Ghacem cement achieved the early highest compressive strength of $28.06 \mathrm{~N} / \mathrm{mm}^{2}$ and last compressive strength of $42.79 \mathrm{~N} / \mathrm{mm}^{2}$ for the $3^{\text {rd }}$ and the $28^{\text {th }}$ curing day. From the graph, the Cimaf cement attained $18.85 \mathrm{~N} / \mathrm{mm}^{2}$ which is the second highest for the day 3 of curing but after the $7^{\text {th }}$ day of curing, Diamond cement overtook Cimaf cement to attain $27.36 \mathrm{~N} / \mathrm{mm}^{2}$ compared to $25.24 \mathrm{~N} / \mathrm{mm}^{2}$ after the $14^{\text {th }}$ day of curing. In all Cimaf attained the lowest compressive of $26.43 \mathrm{~N} / \mathrm{mm}^{2}$ with and Diamond attained the $2^{\text {nd }}$ highest compressive strength of $31.75 \mathrm{~N} / \mathrm{mm}^{2}$ after 28 days of curing. 


\section{CONCLUSIONS}

This research was conducted to analyze the strength of concrete using different types (brands) of cement. The test was conducted on concrete made with the various brands of cement with the same water/ cement ratio and same aggregates. The test was based on only three different brands of cement with a grade of $32.5 \mathrm{R}$ and no additives or admixture was added to the mix. The cement brand used was Ghacem cement, Diamond cement and Cimaf cement.

From the slump test results, it concludes that, Ghacem cement in concrete is more workable compared to the other two cements. Cimaf cement in concrete is the second workable cement before the Diamond cement.

Ghacem gave $42.79 \mathrm{~N} / \mathrm{mm}^{2}$, Diamond $31.75 \mathrm{~N} / \mathrm{mm}^{2}$ but Cimaf had $26.43 \mathrm{~N} / \mathrm{mm}^{2}$. This means that Ghacem achieved the highest compressive strength after 28 days curing and Diamond cement achieved the second highest compressive strength after 28 days curing but Cimaf cement achieved the lowest compressive strength. It was also concluded that the Ghacem cement brand attained progressively increased compressive strength at the earliest age with an average strength of $28.08 \mathrm{~N} / \mathrm{mm}^{2}$ and $42.79 \mathrm{~N} / \mathrm{mm}^{2}$ at the 28 days, making it the cement brand with the highest compressive strength to be attained at the earliest and latest curing age. This high strength of the Ghacem and Diamond cement can be attributed to the addition of a high gaining strength additive in the cement brand. The low strength achieved by the Cimaf cement could also be attributed to the lack of the correct amount of the additives to be added to the cement during production.

\section{RECOMMENDATIONS}

Ghacem cement should be chosen for the construction of concrete related buildings since it produced the maximum compressive strength for the 3 days and 28 days age compared to the other two brands of cements.

In the absence of the Ghacem cement, Diamond cement is the next best cement that will be recommended. This is because Diamond cement achieved the next maximum compressive strength after Ghacem cement.

\section{REFERENCES}

1. Abrams, D. A, (1924), Tests of impure waters for mixing concrete. Proceedings of the American Concrete Institute 20, ACI p. p. 442-86.

2. Barry, R., (1996), The Construction of Buildings $4^{\text {th }}$ Edition.

3. Blezard, Robert G. (2004) "The History of Calcareous Cements" in Hewlett.

4. British Standard, BS-EN 933-1\&3, 1097-5, (Sieve sizes required for grading of aggregates)

5. British Standard, BS-EN 12390-1, 2002, (Part 1: Shape, Dimensions and other requirements for specimens and Moulds)

6. British Standard, BS-EN 12390-2, 2002, (Part 2: Making and Curing specimens for Strength Test)

7. British Standard, BS-EN 12390-3, 2002-2009, (Part 3: Compressive Strength of Test Specimen)

8. Cordon, W. A. and Gillespie, H. A. (1963), "Variables in Concrete Aggregates and Portland Cement Paste Which Influence the Strength of Concrete," ACI Journal, Proceedings V. 60, No.8, August, pp. 1029-1052.

9. Ede, A.N., Egunjobi. E.O., Bamigboye, G.O. and Ogundeji. J. (2015) “Assessment of Quality of Steel Reinforcing Bars Used in Lagos, Nigeria”. International Research Journal of Innovative Engineering. Vol. 1(3) pp. 1-8.

10. Edward G. Nawy, (2008), Concrete Construction Engineering Handbook $2^{\text {nd }}$ Edition 
11. Gabriel A. Nartey, (2016), Investigating the effect of different sources of water on the compressive strength of concrete.

12. H.F.W. Taylor, (1997), Cement Chemistry, $2^{\text {nd }}$ Ed.,Academic Press, London

13. K. Nakatsu, T. Goto, T. Higaki, H. Endo, S. Hirose, and Y. Yamazaki, (1996) Compositions for low heat cements.

14. Kosmatka S.H., Kerkhoff B. and Panarese W.C., (2002), "Design and Control of Mixtures”, Portland cement Association, Skokie, IL. 14th Edition.

15. Liton Biswas, (2013), Cement Ingredients and Their Functions.

16. M.M. Mohsen, (2015), The raw materials used in cement industry.

17. Micheal A. Caldarone, (2009), High Strength Concrete (A Practical Guide).

18. Neville, A.M., (1998), "Properties of Concrete", 4th. Ed., John Wiley \& Sons, Inc., New York, NY, Pitman Publishing Ltd., London, 844 pp.

19. Paulo J.M. Monteiro \& P. Kumar Mehta, (2006), Concrete, Moisture, Properties and Materials.

20. Portland Cement Association, 2002.

21. R. Chudley \& R Greeno, (2006), Building Construction Handbook $8^{\text {th }}$ Edition

22. $R$ Greeno \& R. Chudley, (2010), Building Construction Handbook $8^{\text {th }}$ Edition

23. Rozalija Kozul \& David Darwin, (1997), Effects of aggregate type, size, and content on concrete strength and fracture energy.

24. S. P._Dunuweera and R. M. G._Rajapakse, (2017), Cement Types, Composition, Uses and Advantages of Nanocement, Environmental Impact on Cement Production, and Possible Solutions

25. Technostone, S.P.A. (1984), Study for the exploitation of deposits of lithic materials in Jordan. Carrara, 39p. Rep. Prepared for the Public Mining Co.

26. Teimeh, M. and Hiyari, M. (1978), Pure Limestone deposits in Jordan.

27. Wasiu Ajagbe, Murtadha Adekilekun Tijani(2018), Compressive Strength of Concrete Made from Aggregates of Different Sources, Journal of Research Information in Civil Engineering. 
